\title{
НАУКОВО-КОНЦЕПТУАЛЬНІ ПОЛОЖЕННЯ ОБГРУНТУВАННЯ СУТНОСТІ КАТЕГОРІЇ «СІЛЬСЬКИЙ ЗЕЛЕНИЙ ТУРИЗМ»
}

Татьяна Гакал

\section{НАУЧНО-КОНЦЕПТУАЛЬНЫЕ ПОЛОЖЕНИЯ ОБОСНОВАНИЯ СУЩНОСТИ КАТЕГОРИИ «СЕЛЬСКИЙ ЗЕЛЕНЫЙ ТУРИЗМ»}

\author{
Tetiana Hakal
}

\section{SCIENTIFIC AND CONCEPTUAL PROVISIONS OF THE ESSENCE SUBSTANTIATION OF THE RURAL GREEN TOURISM CATEGORY}

У статті розглянуто питання визначення сутності категорї «сільський зелений туризм». Зокрема, було використано методику контент-аналізу для виокремлення вже сформованих наукових кониепцій трактування сутності цієї дефініціі. Також у статті значну увагу приділено дослідженню сутності таких дефініцій, як «сільський туризм», «агротуризм», «екотуризм». Аналіз їхнього змісту дав змогу поглибити розуміння сутності сільського зеленого туризму через визначення відмінних та спільних рис між окресленими видами туризму, особливостей надання послуг споживачам при реалізачії відповідних туристичних продуктів.

Ключові слова: туризм; сільський туризм; сільський зелений туризм; агротуризм; особисте селянське господарство; екологічний туризм.

Табл.: 2. Бібл.: 31.

В статье рассматрены вопросы определения сущности категории «сельский зеленый туризм». В частности, была использована методика контент-анализа для выделения уже сложивиихся научных концепций трактовки сущности этой дефиниции. Также в статье значительное внимание уделено определнию сушности таких дефиниций, как «сельский туризм», «агротуризм», «экотуризм». Анализ их содержания позволил углубить понимание сущности сельского зеленого туризма путем определения отличных и общих черт между такими видами туризма, особенностей предоставления услуг потребителям при реализации соответствующих туристических продуктов.

Ключевые слова: туризм; сельский туризм; сельский зеленый туризм; агротуризм; личное крестьянское хозяйство; экологический туризм.

Табл.: 2. Библ.: 31

Within the article, the matter of determining the nature of the category "rural green tourism» is researched. In particular, the content analysis technique to highlight already established scientific concepts of the essence interpretation of this definition is used. In addition, within the article, considerable attention is paid to the essence study of such definitions as "rural tourism", "agritourism", "ecotourism". The analysis of their content allowed deepening the understanding of the essence of rural green tourism by identifying distinct and common features between the outlined types of tourism, peculiarities of providing services to consumers by sale of relevant tourism products.

Keywords: tourism; rural tourism; rural green tourism; agritourism; individual peasant economy; ecotourism.

Table: 2. References: 31.

JEL Classification: L83; Q26; R22; Q19

Постановка проблеми. Україна - аграрна країна з потужним потенціалом для розвитку сільського господарства, виробництва аграрної продукції. Саме українське село як центр функціонування аграрних підприємств на сьогодні внаслідок впливу різних факторів політичної, соціальної і насамперед економічної дії кардинально змінилося i поступово занепадає. Суттєві міграційні процеси, занепад раніше діючих аграрних господарств, колгоспів, низький рівень соціального забезпечення та відсутність роботи змусили значну кількість сільських мешканців мігрувати до великих міст, районних центрів. Такі процеси набули національного масштабу, а при поступовому відновленні

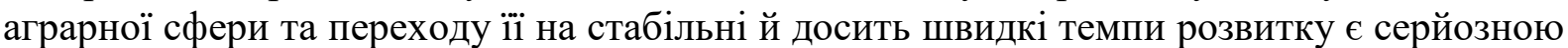
проблемою для їх функціонування. Дефіцит трудових ресурсів на сьогодні в цій сфері відчувається особливо гостро.

Більшість урядів країни не приділяли належної уваги проблемі працевлаштування сільських мешканців, що значно прискорило деструктивні процеси в розвитку українського села. Відсутність реально діючих та конкурентоспроможних підприємств, які б давали роботу людям i, відповідно, дохід, призвели в підсумку до його фактичного занепаду. Отже, існування проблеми соціально-економічної розбудови села вимагає

(c) Гакал Т. О., 2019 
ГАЛУЗЕВИЙ АСПЕКТ РОЗВИТКУ НАЦІОНАЛЬНОГО ГОСПОДАРСТВА

пошуку нових способів іiї вирішення. Частково, як засвідчує вітчизняний та закордонний досвід, іiі можна вирішувати через активізацію функціонування не лише аграрних виробництв, але й інших, суміжних сфер господарської діяльності. До них можна віднести і сферу сільського зеленого туризму.

Сільський зелений туризм є однією з небагатьох сфер економіки, яка може розвиватися виключно в сільській місцевості, використовуючи вже наявний потенціал країни, iї окремих територій та не вимагає залучення значних інвестицій. Перевагою такого виду туризму є його фінансова доступність для туристів, простота в організації відпочинку для власників та постійний попит мешканців великих міст на відпочинок за межами міських агломерацій.

Аналіз останніх досліджень і публікацій. Враховуючи важливість розвитку сільського зеленого туризму для сільських територій, залучення сільського населення до господарської діяльності, питання розвитку цього виду туризму досить активно досліджуються вченими. До їх числа варто віднести таких українських науковців: О. Бордун, I. Власенко, М. Габа, І. Гришова, Н. Добрянська, О. Кловчковський, О. Корчинська, А. Кравчук, І. Крюкова, С. Мазур, А. Матвієнко, В. Маховка, В. Папп, В. Пеньковський, В. Савченко, А. Сакун, Г. П. Скляр, Ю. Ставська, В. Степанов, А. Стренковська, І. Тищук та їхніх іноземних колег: G. Butnaru, C. Cergeau, E. Citro, J. Chen, W. Chen, H. Fu, J. Guan, G. Gonçalves, A. González-Ramiro, A. Haller, B. Hu, J. Jeong, H. Li, G. Quaranta, R. Salvia, A. Sánchez-Ríos, A. Trukhachev, J. Xu, X. Yang, T. Zhang та ін.

Зокрема, В. Пеньковський проводив дослідження у сфері аналізу особливостей формування та розвитку господарств сільського зеленого туризму, О. Корчинська значну увагу приділила вивченню розвитку підприємництва у сфері сільського зеленого туризму, а I. Тищук провела грунтовний аналіз регіональних механізмів стимулювання підприємництва у сфері сільського зеленого туризму.

Виділення недосліджених частин загальної проблеми. Проте, попри численні напрацювання науковців у сфері дослідження категоріального апарату функціонування системи сільського зеленого туризму, нині залишаються актуальними питання виокремлення наукових концепцій трактування сутності окресленого виду туризму, уточнення його змісту та визначення специфічних рис.

Мета статті. Метою статті є проведення грунтовного аналізу сформованих наукових концепцій щодо розгляду сутності категорії «сільський зелений туризм» та визначення авторського підходу до трактування цієї дефініції.

Виклад основного матеріалу. Спочатку визначимо сутність сільського зеленого туризму як економічного явища та наукової категорії. Зазначимо, що окремі аспекти розуміння його змісту на сьогодні вже визначені у вітчизняному законодавчому полі. Зокрема, у статті 4 Закону України «Про туризму» залежно від категорій осіб, які здійснюють туристичні подорожі (поїздки, відвідування), їхніх цілей, об'єктів, що використовуються або відвідуються, виділяється низка видів туризму, серед яких виокремлено сільський та окремо екологічний (зелений) туризм [21].

У Законі України «Про особисте селянське господарство» сферу сільського зеленого туризму віднесено до послуг особистих селянських господарств, які можуть ними надаватися. У цьому законодавчому акті зазначено, що особисте селянське господарство - це господарська діяльність, яка проводиться без створення юридичної особи фізичною особою індивідуально або особами, які перебувають у сімейних чи родинних відносинах і спільно проживають, 3 метою задоволення особистих потреб шляхом виробництва, переробки і споживання сільськогосподарської продукції, реалізації іiі надлишків та надання послуг із використанням майна особистого селянського господарства, у тому числі й у сфері сільського зеленого туризму [20]. 
ГАЛУЗЕВИЙ АСПЕКТ РОЗВИТКУ НАЦІОНАЛЬНОГО ГОСПОДАРСТВА

Аналізуючи підходи до з'ясування сутності сільського зеленого туризму, що наводяться в законодавчих документах, можна констатувати, що в їхніх межах не сформульовано чіткого розуміння цього виду туризму, його підвидів, специфіки надання відповідних послуг. Отже, існує необхідність проведення контент-аналізу наукових робіт, в яких вивчаються окреслені питання.

Також варто зазначити, що попередній аналіз проведених досліджень свідчить про наявність різних економічних категорій, які активно використовуються вченими для проведення досліджень у цій сфері. Зокрема, науковці розглядають окремо такі дефініції, як «сільський туризм», «аграрний туризм», «екологічний туризм», «зелений туризм» та ін. Тобто категорію «сільський зелений туризм» багато науковців розглядають по-різному. Багато учених виділяє та досліджує виключно «сільський туризм». Інші дослідники активно аналізують особливості надання послуг із зеленого туризму як окремого виду туризму. Відповідно, виникає певна поліструктурність розуміння окреслених вище категорій. Це зумовлює необхідність визначення сутності окреслених вище дефініцій, що дозволить глибше обгрунтувати зміст категорії «сільський зелений туризм».

Дослідження розпочнемо 3 аналізу змісту категорії «сільський туризм». У табл. 1 представлено окремі концепції розгляду сутності цієї категорії.

Таблиця 1

Наукові концепиії обтрунтування сутності дефініції «сільський туризм»

\begin{tabular}{|c|c|}
\hline Сутність категорії & Джерело \\
\hline 1 & 2 \\
\hline $\begin{array}{l}\text { Сільський туризм (rural tourism) - відпочинковий вид ту- } \\
\text { ризму, сконцентрований на сільських територіях. } \\
\text { Сільський туризм - це форма проведення вільного часу у } \\
\text { вигляді стаціонарного відпочинку, тоді як базовою метою } \\
\text { екотуризму виступає активне відкриття дикої природи, } \\
\text { традицій і культури, їх глибоке пізнання й сприйняття [7]. }\end{array}$ & $\begin{array}{l}\text { Горішевський П. В., Васильєв В. П., Зінь- } \\
\text { ко Ю. В. Сільський зелений туризм: органі- } \\
\text { зація гостинності на селі: підручник. Івано- } \\
\text { Франківськ: Місто-Н, 2003. } 148 \text { с. }\end{array}$ \\
\hline $\begin{array}{l}\text { Сільський туризм - один із різновидів господарської дія- } \\
\text { льності, у тому числі із залученням майна особистого } \\
\text { селянського господарства, шляхом надання послуг із } \\
\text { тимчасового проживання, харчування, проведення відпо- } \\
\text { чинку, практичний показ процесів вирощування та догля- } \\
\text { ду за рослинами, тваринами та бджолами, а також з виго- } \\
\text { товлення виробів } 3 \text { глини, вишивання, різьба по дереву, } \\
\text { лозоплетіння та ін., народних обрядів, ознайомлення ту- } \\
\text { ристів з побутом та умовами проживання селян минулого } \\
\text { століття, з особливостями регіону, його пам'ятками, при- } \\
\text { родним ландшафтом тощо [13]. }\end{array}$ & $\begin{array}{l}\text { Інформаційно-аналітичний портал АПК Ук- } \\
\text { раїни. URL: https://agro.me.gov.ua/ua/ } \\
\text { napryamki/rozvitok-silskih-teritorij/silskij- } \\
\text { turizm. }\end{array}$ \\
\hline $\begin{array}{l}\text { Сільській туризм - відпочинковий вид туризму, що пе- } \\
\text { редбачає тимчасове перебування туристів у сільській міс- } \\
\text { цевості (селі) [22]. }\end{array}$ & $\begin{array}{l}\text { Проєкт Закону України «Про сільський та } \\
\text { сільський зелений туризм». URL: } \\
\text { http://w1.c1.rada.gov.ua/pls/zweb2/webproc4_- } \\
\text { 2?pf3516=4299\&skl=5. }\end{array}$ \\
\hline $\begin{array}{l}\text { Сільський туризм є відносно новим і перспективним на- } \\
\text { прямом, що дозволяє жителям міст долучитися до тради- } \\
\text { ційного укладу життя сільських жителів. Суть даного } \\
\text { виду туризму полягає у відпочинку в сільській місцевос- } \\
\text { ті, де все організаційне забезпечення проживання турис- } \\
\text { тів (у тому числі харчування, дозвілля, обслуговування та } \\
\text { iн.) бере на себе приймаюча сім'я [18, с. 19]. }\end{array}$ & $\begin{array}{l}\text { Папп В. В. Сільський зелений туризм як } \\
\text { пріоритетний напрям розвитку сільських } \\
\text { територій України. Агросвіт. 2015. № } 18 . \\
\text { С. 17-22. }\end{array}$ \\
\hline $\begin{array}{l}\text { Сільський туризм - це туризм, який проходить у сільсь- } \\
\text { кому поселенні, де базовою точкою є сільська садиба } 3 \\
\text { повним комплексом турпослуг [5]. }\end{array}$ & $\begin{array}{l}\text { Габчак Н. Сільський туризм Закарпаття. } \\
\text { Збірник наукових статей викладачів кафе- } \\
\text { дри суспільних дисциплін Закарпатського } \\
\text { державного ун-ту. 2008. Вип. 2. С. 12-19. }\end{array}$ \\
\hline
\end{tabular}


Закінчення табл. 1

\begin{tabular}{|c|c|}
\hline 1 & 2 \\
\hline $\begin{array}{l}\text { Сільський туризм - це є різновид зеленого туризму, що } \\
\text { передбачає розміщення туристів у сільській садибі для } \\
\text { відпочинку та отримання ними послуг сільського туриз- } \\
\text { му; надання послуг сільського (зеленого) туризму є сус- } \\
\text { пільно-корисною діяльністю, що сприяє соціально- } \\
\text { економічному, культурному та екологічному розвитку } \\
\text { сільської місцевості [19]. }\end{array}$ & $\begin{array}{l}\text { Пилипенко Г. М., Прушківська Е. В., Куса- } \\
\text { кова Ю. О. Компаративний аналіз розвитку } \\
\text { зеленого туризму в Україні та світі. Еконо- } \\
\text { мічний вісник. 2016. № 3. С. 145-153. }\end{array}$ \\
\hline $\begin{array}{l}\text { Сільський туризм (rural tourism) - відпочинковий вид ту- } \\
\text { ризму, сконцентрований на сільських територіях. Він пе- } \\
\text { редбачає розвиток туристичних шляхів, місць для відпо- } \\
\text { чинку, сільськогосподарських і народних музеїв, а також } \\
\text { центрів з обслуговування туристів } 3 \text { провідниками та екс- } \\
\text { курсоводами }[24, \text { с. } 88] \text {. }\end{array}$ & $\begin{array}{l}\text { Сердюкова О. М. Сутність сільського зеле- } \\
\text { ного туризму. Економіка та держава. } 2014 . \\
\text { № 3. С. 87-90. }\end{array}$ \\
\hline
\end{tabular}

Джерело: складено автором.

Аналізуючи дані табл. 1 варто зауважити, що безпосередньо сільський туризм пов'язаний із наданням відповідних послуг у межах певної сільської місцевості. Зокрема, В. В. Папп відзначає, що «сільський туризм є відносно новим і перспективним напрямом, що дозволяє жителям міст долучитися до традиційного укладу життя сільських жителів. Суть цього виду туризму полягає у відпочинку в сільській місцевості, де все організаційне забезпечення проживання туристів бере на себе приймаюча сім'я» [18, с. 19]. П. В. Горішевський, В. П. Васильєв, Ю. В. Зінько констатують, що «сільський туризм (rural tourism) - відпочинковий вид туризму, сконцентрований на сільських територіях» [7]. Отже, можна зазначити, що сільський туризм являє собою тимчасовий виїзд людини 3 місця постійного проживання з оздоровчою, пізнавальною або професійно-діловою метою без заняття оплачуваною діяльністю до сільської місцевості.

Розглянемо тепер сутність таких окремих дефініцій, як «аграрний туризм», «екологічний туризм», «зелений туризм». Цілком доцільно зауважити, що окреслені види туризму є складовими за своїм змістом сільського туризму, оскільки в переважній більшості випадків об'єктивно можуть надаватися виключно в сільській місцевості. Проте їх відмінність між собою вимагає уточнення та конкретизації.

Розглянемо специфічні риси аграрного туризму. У проєкті Закону України «Про аграрний туризм та агротуристичну діяльність» пропонується таке визначення сутності аграрного туризму - вид туризму як відпочинкового, так і пізнавального характеру, пов'язаний із використанням майна особистих селянських господарств, що передбачає здійснення агротуристичної діяльності під час тимчасового перебування туристів у сільській місцевості. Відповідно, агротуристична діяльність визначається як діяльність особистого селянського господарства, спрямована на задоволення потреб туристів та надання їм агротуристичних послуг, а агротутистичні послуги - це тимчасове розміщення, харчування, екскурсійне, спортивне, розважальне, культурно-просвітницьке та інше обслуговування туристів [22].

Розгляд сутності аграрного туризму дозволяє стверджувати, що за своїм змістом він $\epsilon$ різновидом сільському туризму, оскільки йому притаманні всі ознаки здійснення відпочинку в сільській місцевості. Зокрема, у підручнику «Сільський зелений туризм» агротуризм пропонується розглядати як «форму сільського туризму, яка безпосередньо пов'язана із селянським (фермерським) господарством, що одночасно надає послуги 3 проживання та харчування, знайомить із сільськогосподарською діяльністю, традиціями та звичаями цього регіону» [25]. У свою чергу, Н. В. Дідик, О. В. Варшава пропонують розглядати агротуризму «як сектор туристичної галузі, орієнтований на використання природних, культурно-історичних та інших ресурсів сільської місцевості й їі специфіки для створення комплексного туристичного продукту» [10, с. 764]. О. М. Сердюкова трактує сутність досліджуваного виду туризму так: «агротуризм - 
ГАЛУЗЕВИЙ АСПЕКТ РОЗВИТКУ НАЦІОНАЛЬНОГО ГОСПОДАРСТВА

відпочинковий туризм, що передбачає використання сільського (фермерського) господарства. Агрогуризм може проявлятись у різних формах, але завжди включає винаймання помешкання» [24, с. 89]. Отже, окремими специфічними рисами, що виділяють цей вид туризму з усіх інших видів сільського туризму, є:

1) відпочинок відбувається виключно в сільській місцевості;

2) здійснюється ознайомлення туристів з особливостями ведення сільського господарства, залучення їх до сільськогосподарських робіт;

3) проживання відбувається в сільській садибі господаря або на фермі, яка обладнана всім необхідним для цього виду відпочинку.

Варто зазначити, що за своєю сутність аграрний туризм є сільським туризмом, оскільки його притаманні всі характерні риси здійснення відпочинку в селі.

Розглядаючи сутність екологічного туризму, доцільно зауважити, що за своєю сутністю саме цей виду туризму тісно пов'язаний із проживанням у сільській місцевості, однак це відбувається не завжди, що й обгрунтовує різницю між цими двома видами туризму. Розглянемо сутність екологічного туризму (екотуризму) більш детально. Наведено декілька концепцій розгляду змісту такого виду туризму:

1) екотуризм - організація гостям відпочинку в екологічно чистій місцевості, вживання екологічно чистої продукції, сприяння в заготівлі лікарських трав, лісових ягід і грибів [6, с. 43];

2) екотуризм - організація подорожей з обмеженою кількістю учасників у природні зони 3 можливим відвідуванням місць, що є культурною цінністю та з метою реалізації різних проектів охорони й раціонального використання природних ресурсів [27];

3) екотуризм (зелений туризм) - форма активного й безпосереднього відвідування територій з особливими природними та культурними умовами. Екотуризм спрямований на охорону природного й культурного середовища регіонів, які відвідують туристи [25];

4) екотуризм - це форма подорожі, сприятлива для навколишнього середовища. Вона відбувається на територіях, що мають природничу цінність (національні та ландшафтні парки). Екотуризм спрямований на охорону природного й культурного середовища регіонів, які відвідуються туристами [10, с. 764].

Аналізуючи окреслені підходи до розгляду сутності екотуризму, можна визначити такі особливості цього виду туризму:

1) відвідування екологічно чистих територій туристами;

2) споживання екологічно чистих продуктів;

3) можливе відвідування національних парків та заповідників;

4) проживання відбувається не обов'язково в сільській садибі, а може здійснюватися в палатках, спеціально відведених місцях;

5) під час такого туризму відбувається, насамперед, пізнання природи, що може супроводжуватися також відсутністю певних умов для зручного проживання;

6) шанобливе ставлення до природи, мінімізація впливу людини на природу при відпочинку $[11 ; 12 ; 34]$.

Отже, аналіз представлених підходів до розуміння сутності екотуризму свідчить про існування значної різниці між цим видом туризму та сільським туризмом. Основна особливість полягає передусім у тому, що екотуризм не завжди пов'язаний із сільською територією, місцевістю, де проживають на постійні основі люди. Проте, з іншого боку, це не означає, що туристи, які хочуть займатися екотуризмом, не можуть зупинятися для ночівлі в сільських господарствах або недалеко від сільських поселень. Відповідно, зазначене дає підстави стверджувати, що сільський та екологічний туризм, навіть за існування значних відмінностей між ними, дуже тісно взаємопов'язані. Це також частково зумовлено наявністю значної кількість різних форматів відпочинку. 
ГАЛУЗЕВИЙ АСПЕКТ РОЗВИТКУ НАЦІОНАЛЬНОГО ГОСПОДАРСТВА

Розглянемо сутність саме «зеленого туризму» як одного з різновидів сільського туризму. Зауважимо, що досить часто в науковій літературі сільський туризм та сільський зелений туризм розглядаються як синонімічні поняття, які, на думку вчених, нероздільно пов’язані між собою. Зокрема, В. Г. Дарчук зазначає, що сільський (зелений) туризм вид туризму, що передбачає розміщення туристів у сільській садибі для відпочинку та отримання ними відповідних послуг (традиційних основних: проживання (екологічне, культурне, історичне розташування), харчування (екологічно чисті продукти, дегустація місцевих (домашніх) страв), розваг (участь у фестивалях, ярмарках, організації традиційних свят); традиційних додаткових: робота на фермі, городі, в саду, на господарському дворі, сіновалі, рибалка, полювання та специфічних: догляд за домашніми тваринами, катання на конях, човнах, навчання народним ремеслам тощо) [9]. В. Ф. Савченко, В. О. Стойка зауважують у свої статті, що «поняття «сільський туризм», або, як його ще називають “сільський зелений туризм”, означає відпочинок у сільській садибі» [23, с. 6].

Загалом зелений туризм визначається як спрямована мандрівка в сільську місцевість 3 метою ознайомлення 3 місцевою культурою та історією природного середовища, яка не порушує цілісності екосистеми, при цьому робить охорону природних ресурсів вигідною для сільських мешканців. Важливою функцією зеленого туризму є збереження та розвиток культурно-історичної спадщини, народних промислів, охорона природного середовища [2]. В. Смолій, В. Федорченко, В. Цибух зауважують, що зелений туризм - діяльність, яка проходить у контакті з природою, проживанням у таборах чи сільській місцевості та пов'язана із сільськогосподарськими роботами, знайомством 3 життям сільських мешканців, пішохідними екскурсіями, вивченням флори і фауни, зайняттям річковим спортом та ін. [26].

Розглянемо сутність категорії «сільський зелений туризм» більш детально. Для цього проведемо аналіз тих підходів до розуміння цієї дефініції, що трапляється в науковій літературі. Результати такого аналізу представлені в табл. 2.

Таблиця 2

Наукові концепції розгляду сутності дефініциї «сільський зелений туризм»

\begin{tabular}{|c|c|}
\hline Сутність категорії & Джерело \\
\hline 1 & 2 \\
\hline $\begin{array}{l}\text { Сільський зелений туризм - це заснований на договорі специфі- } \\
\text { чний вид туризму, що має рекреаційний, відпочинковий, оздо- } \\
\text { ровчий та/або пізнавальний характер, зосереджений у сільській } \\
\text { місцевості і пов'язаний з наданням послуг (з тимчасового роз- } \\
\text { міщення, харчування, екскурсійного забезпечення тощо) фізич- } \\
\text { ним особам шляхом використання майна, земельних ділянок та } \\
\text { трудових ресурсів осіб, які займаються сільськогосподарською } \\
\text { діяльністю та/або проживають у сільській місцевості, а також } \\
\text { природного, культурного, етнографічного та соціального потен- } \\
\text { ціалу регіону [29, с. } 104] \text {. }\end{array}$ & $\begin{array}{l}\text { Туєва О. М. Правові умови забезпе- } \\
\text { чення діяльності у сфері зеленого } \\
\text { туризму. Порівняльно-аналітичне } \\
\text { право: електрон. наук. фах. вид. юрид. } \\
\text { ф-ту ДВНЗ «Ужгород. нац. ун-т». } \\
\text { 2017. № 3. С. } 103-106 .\end{array}$ \\
\hline $\begin{array}{l}\text { Сільський зелений туризм можна розглядати як проведення ві- } \\
\text { льного часу в сільському середовищі, в якому існує відповідна } \\
\text { забудова, сільський побут, етнокультурний колорит місцевості } \\
\text { тощо }[28] \text {. }\end{array}$ & $\begin{array}{l}\text { Транченко Л. В., Тимчук С. В., Неща- } \\
\text { дим Л. Н. Соціальне значення зелено- } \\
\text { го туризму в контексті розвитку сіль- } \\
\text { ських територій України. Сучасні } \\
\text { mехнологї̈ управління. 2015. № } 1 \text { (49). } \\
\text { URL: https://sovman.ru/article/4908. } \\
\end{array}$ \\
\hline $\begin{array}{l}\text { Сільський зелений туризм - це специфічна форма відпочинку в } \\
\text { селі з використанням природного, матеріального та культурного } \\
\text { потенціалу даної місцевості. При цьому проживання, харчуван- } \\
\text { ня та обслуговування туристів забезпечує сільська родина [3]. }\end{array}$ & $\begin{array}{|lcrr|}\text { Васильєв } & \text { В. П. } & \text { Сільський } & \text { зелений } \\
\text { туризм } & \text { в } & \text { Україні. } & \text { URL: } \\
\text { http://tourlib.net/statti_ukr/vasyljev.htm. }\end{array}$ \\
\hline $\begin{array}{l}\text { Сільський зелений туризм - специфічна форма відпочинку в } \\
\text { приватних господарствах сільської місцевості } 3 \text { використанням } \\
\text { майна та трудових ресурсів особистого селянського, підсобного } \\
\text { або фермерського господарства, природно-рекреаційних особ- } \\
\text { ливостей місцевості, а також культурної, історичної та етногра- } \\
\text { фічної спадщини регіону [1]. }\end{array}$ & $\begin{array}{l}\text { Биркович В. І. Сільський зелений ту- } \\
\text { ризм - пріоритет розвитку туристичної } \\
\text { галузі України. Стратегічні пріорите- } \\
\text { mu: науково-аналітичний щокварталь- } \\
\text { ний збірник. 2008. № } 1 \text { (6). С. 138-143. }\end{array}$ \\
\hline
\end{tabular}


Закінчення табл. 2

\begin{tabular}{|c|c|}
\hline 1 & 2 \\
\hline $\begin{array}{l}\text { Сільський, зелений туризм - тимчасове переміщення туристів у } \\
\text { сільську місцевість } 3 \text { метою відпочинку та ознайомлення з міс- } \\
\text { цевим способом життя, культурою, традиціями, звичаями. Цей } \\
\text { вид туризму часто використовують сім'ї з дітьми, міська молодь, } \\
\text { які намагаються вибратись на природу на вихідні дні або в ко- } \\
\text { роткотермінові відпустки [14]. }\end{array}$ & $\begin{array}{l}\text { Кифяк В. Ф. Організація туристичної } \\
\text { діяльності в Україні. Навчальний посі- } \\
\text { бник. Чернівці: Книги-XXI, 2003. } 300 \text { c. } \\
\text { Режим доступу: http://tourlib.net/ } \\
\text { books_ukr/kyfjak_3.htm. }\end{array}$ \\
\hline $\begin{array}{l}\text { Сільський зелений туризм - це сучасна тенденція у туристичній } \\
\text { сфері, що характеризується наданням послуг гостинності турис- } \\
\text { там, що надаються господарем агрооселі (особисте селянське } \\
\text { господарство), яка знаходиться у сільській місцевості [30, с. 40]. }\end{array}$ & $\begin{array}{l}\text { Язіна В. А, Ткач В. О., Кожушко С. П. } \\
\text { Сільський зелений туризм як основ- } \\
\text { ний інструмент створення успішного } \\
\text { українського туристичного села. При- } \\
\text { чорноморські економічні студії. } 2018 . \\
\text { Випуск 29. С. 37-41. }\end{array}$ \\
\hline $\begin{array}{l}\text { Сільський зелений туризм - це добровільне надання за плату } \\
\text { або безоплатно послуги у сфері сільського зеленого туризму, а } \\
\text { саме послуги з розміщення (проживання) не більше ніж на } 10 \\
\text { місць, харчування, а також організації дозвілля й заходів, } \\
\text { пов'язаних із використанням майна особистого селянського го- } \\
\text { сподарства, місцевими звичаями і традиціями гостинності [15]. }\end{array}$ & $\begin{array}{l}\text { Мазур С. А. Сільський туризм як пер- } \\
\text { спективний напрям розвитку внутрі- } \\
\text { шнього туризму. Ефективна економі- } \\
\text { ка. 2018. № 2. Режим доступу: } \\
\text { http://www.economy.nayka.com.ua/?op } \\
=1 \& \mathrm{z}=6122 \text {. }\end{array}$ \\
\hline $\begin{array}{l}\text { Сільський зелений туризм - це відпочинковий вид туризму, що } \\
\text { передбачає тимчасове перебування туристів у сільській місцево- } \\
\text { сті (селі) та отримання ними послуг сільського зеленого туризму } \\
3 \text { використанням майна та трудових ресурсів особистого селян- } \\
\text { ського, підсобного або фермерського господарства, природно- } \\
\text { рекреаційних особливостей місцевості та культурної, історичної } \\
\text { та етнографічної спадщини регіону [16]. }\end{array}$ & $\begin{array}{l}\text { Матвієнко А. Т. Зелений туризм як } \\
\text { напрямок вирішення проблеми зайня- } \\
\text { тості сільського населення в Україні. } \\
\text { Економічний вісник університету. } \\
\text { 2014. Вип. 22(1). C. 95-99. URL: } \\
\text { http://nbuv.gov.ua/UJRN/ecvu_2014_22 } \\
\% 281 \% 29 \quad 18 .\end{array}$ \\
\hline $\begin{array}{l}\text { Сільський зелений туризм як вид підприємницької } 224 \text { діяльно- } \\
\text { сті, спрямованої на надання послуг із відпочинку в сільській } \\
\text { місцевості та отримання доходів, що функціонує за законами } \\
\text { ринку і є специфічною, особливою складовою механізму функ- } \\
\text { ціонування аграрного сектору економіки загалом }[4, \text { с. 223-224]. }\end{array}$ & $\begin{array}{l}\text { Власенко І. В., Іващенко Г. В. Функці- } \\
\text { онування сільського зеленого туризму } \\
\text { в умовах ринкової економіки України. } \\
\text { Економічна стратегія } і \text { перспективи } \\
\text { розвитку сфери торгівлі та послуг. } \\
\text { 2017. Вип. } 1 \text { (25). С. 218-233. }\end{array}$ \\
\hline
\end{tabular}

Джерело: складено автором.

Аналіз окреслених у табл. 2 наукових підходів до розгляду сутності сільського зеленого туризму свідчить, що в науковій літературі існують відмінні концепції розгляду змісту цієї категорії. Більшість учених розглядають цю дефініцію як окремий вид туризму, якому притаманна своя специфіка та особливості здійснення. О. М. Туєва зазначає, що «сільський зелений туризм - це заснований на договорі специфічний вид туризму, що має рекреаційний, відпочинковий, оздоровчий та/або пізнавальний характер, зосереджений у сільській місцевості й пов'язаний із наданням послуг фізичним особам шляхом використання майна, земельних ділянок та трудових ресурсів осіб, які займаються сільськогосподарською діяльністю та/або проживають у сільській місцевості, а також природного, культурного, етнографічного та соціального потенціалу регіону» [29, с. 104]. 3 іншого боку, деякі науковці розглядають сільський зелений туризм як просто окрему форму відпочинку. Серед цих учених варто відзначити таких: П. В. Горішевський, В. П. Васильєв, В. І. Биркович, Л. І. Оппельд, О. Г. Розметова, Н. Ю. Сидорук та ін. Зокрема, В. П. Васильєв стверджує, що «сільський зелений туризм - це специфічна форма відпочинку в селі з використанням природного, матеріального та культурного потенціалу даної місцевості. При цьому проживання, харчування та обслуговування туристів забезпечує сільська родина» [3]. Окреслені підходи щодо розгляду сутності сільського туризму дають підстави стверджувати, що є певна відмінність між ними. Для ії визначення, розглянемо також сутність категорії «туризм». 
ГАЛУЗЕВИЙ АСПЕКТ РОЗВИТКУ НАЦІОНАЛЬНОГО ГОСПОДАРСТВА

У Законі України «Про туризм» зазначено, що «туризм - тимчасовий виїзд особи 3 місця проживання в оздоровчих, пізнавальних, професійно-ділових чи інших цілях без здійснення оплачуваної діяльності в місці, куди особа від'їжджає» [21]. I. М. Писаревський, С. О. Погасій, М. М. Поколодна, грунтуючись на підході Всесвітньої туристської організації, зазначають, що «туризм - тимчасовий виїзд людини 3 місця постійного проживання з оздоровчою, пізнавальною або професійно-діловою метою без заняття оплачуваною діяльністю» [17, с. 18].

Таким чином, враховуючи окреслені концепції розгляду туризму як економічної категорії, можна стверджувати, що виокремленні вище підходи до розгляду сутності саме дефініції «сільський зелений туризм»є правильними. Принциповою різницею між ними $є$ лише те, що в першому випадку вчені акцентують увагу саме на тому, що сільський зелений туризм $є$ одним із видів туризму зі специфічними ознаками його проведення, а у іншому - як спосіб проведення часу мешканцями міст та міських агломерацій. Л. В. Транченко, С. В. Тимчук, Л. Н. Нещадим зауважують, що «сільський зелений туризм можна розглядати як проведення вільного часу в сільському середовищі, в якому існує відповідна забудова, сільський побут, етнокультурний колорит місцевості тощо» [28]. У цьому випадку при дослідженні сутності сільського зеленого туризму більшу увагу приділяють самій формі, наповненню такого відпочинку різними послугами та враженнями. При розгляді цієї окресленої категорії як виду туризму, акцент насамперед робиться на його організації, особливостях надання відповідних туристичних послуг. Отже, перший підхід щодо розгляду сутності сільського зеленого туризму пов'язаний із розглядом його з позиції виробника відповідних послуг, а інший - 3 позиції їх використання, тобто споживача.

Висновки і пропозиції. Отже, у статті розглянуто сутність таких категорій, як «сільський туризм», «агротуризм», «екотуризм». Аналіз сутності окреслених категорій дозволив обгрунтувати зміст сільського зеленого туризму, визначити його відмінності від аграрного та екологічного туризму. Для реалізації окресленого було проведено контентаналіз сформованих у наукових роботах підходів до розгляду сутності таких видів туризму. Таким чином, сільський зелений туризм пропонується розглядати як вид туризму, сутність якого полягає у здійсненні тимчасового виїзду людини до сільської місцевості, проживанні в сільській садибі господаря, що здійснюється з метою відпочинку, ознайомлення $з$ національними традиціями та особливостями сільського життя, долученням до природи, що не супроводжується наданням відпочивальникам будь-яких платних послуг.

Проведене дослідження дає підстави стверджувати, що питання розвитку сільського зеленого туризму на сьогодні розглядаються у великій кількості наукових робіт. Проте незначна їх кількість стосується дослідження особливостей проведення господарської діяльності підприємствами в цій сфері. Отже, зазначені напрями є актуальними для здійснення подальших наукових досліджень у сфері розвитку сільського зеленого туризму в Україні.

\section{Список використаних джерел}

1. Биркович В. І. Сільський зелений туризм - пріоритет розвитку туристичної галузі України. Стратегічні пріоритети: науково-аналітичний щоквартальний збірник. 2008. № 1 (6). С. 138-143.

2. Васильєв В. Головна мета сільського туризму - це новий туристичний продукт. Туризм сільський зелений. 2008. № 4. С. 10-13.

3. Васильєв В. П. Сільський зелений туризм в Україні. URL: http://tourlib.net/statti_ukr/ vasyljev.htm.

4. Власенко І. В., Іващенко Г. В. Функціонування сільського зеленого туризму в умовах ринкової економіки України. Економічна стратегія і перспективи розвитку сфери торгівлі та послуг. 2017. Вип. 1 (25). С. 218-233.

5. Габчак Н. Сільський туризм Закарпаття. Збірник наукових статей викладачів кафедри суспільних дисииплін Закарпатського державного ун-ту. 2008. Вип. 2. С. 12-19.

6. Гончаров Ю. В. Сільський зелений туризм як перспективний напрям розвитку загального піднесення економічного рівня регіону. Інтелект XXI. 2014. № 3. С. 41-45. 
ГАЛУЗЕВИЙ АСПЕКТ РОЗВИТКУ НАЦІОНАЛЬНОГО ГОСПОДАРСТВА

7. Горішевський П. В., Васильєв В. П., Зінько Ю. В. Сільський зелений туризм : організація гостинності на селі: підручник. Івано-Франківськ: Місто-Н, 2003. 148 с.

8. Горьовий В. П., Тимчук С. В. Менеджмент фермерський господарств: навч. посіб. Київ: ЦУЛ, 2014. 366 с. URL: https://pidruchniki.com/1278021261738/menedzhment/sotsialnoekonomichne_znachennya_fermerskogo_turizmu_konteksti_rozvitku_silskih_teritoriy_ukrayiniю.

9. Дарчук В. Г. Формування стратегічних основ розвитку сільського (зеленого) туризму в Україні: автореф. дис. ... канд. екон. наук: спец. 8.00.03 / Донец. нац. ун-т економіки і торгівлі ім. Михайла Туган-Барановського. Донецьк, 2014. 21 с.

10. Дідик Н. В., Варшава О. В. Розвиток зеленого туризму - пріоритетне завдання для України. Економіка та суспільство. 2017. Вип. 9. С. 763-767.

11. Добрянська Н. А., Стоянова-Коваль С. С., Ніколюк О. В. Реалії сьогодення та перспективи розвитку туристичного бізнесу Одеської області. Економіка харчової промисловості. 2018. № 10(1). С. 9-15.

12. Дубина М. В., Пілевич Д. С. Проблеми активізації формування та залучення інвестицій у розвиток національної економіки. Науковий Вісник: фінанси, банки, інвестичії. 2014. № 1(26). С. 94-101.

13. Інформаційно-аналітичний портал АПК України. URL: https://agro.me.gov.ua/ua/ napryamki/rozvitok-silskih-teritorij/silskij-turizm.

14. Кифяк В. Ф. Організація туристичної діяльності в Україні: навч. посіб. Чернівці: КнигиXXI, 2003. 300 c. URL: http://tourlib.net/books ukr/kyfjak 3.htm.

15. Мазур С. А. Сільський туризм як перспективний напрям розвитку внутрішнього туризму. Ефективна економіка. 2018. № 2. URL: http://www.economy.nayka.com.ua/?op=1\&z=6122.

16. Матвієнко А. Т. Зелений туризм як напрямок вирішення проблеми зайнятості сільського населення в Україні. Економічний вісник університету. 2014. Вип. 22(1). С. 95-99. URL: http://nbuv.gov.ua/UJRN/ecvu_2014_22\%281\%29_18.

17. Організація туризму: підручник / за ред. І. М. Писаревського. Харків: ХНАМГ, 2008. 541 с.

18. Папп В. В. Сільський зелений туризм як пріоритетний напрям розвитку сільських територій України. Агросвіт. 2015. № 18. С. 17-22.

19. Пилипенко Г. М., Прушківська Е. В., Кусакова Ю. О. Компаративний аналіз розвитку зеленого туризму в Україні та світі. Економічний вісник. 2016. № 3. С. 145-153.

20. Про особисте селянське господарство: Закон України від 15.05.2003 № 742-IV. URL: https://zakon.rada.gov.ua/laws/show/742-15/print.

21. Про туризм: Закон України від 15.09.1995 № 324/95-BP. URL: https://zakon.rada.gov.ua/ laws/show/324/95-\%D0\%B2\%D1\%80/print. $1 \Gamma$.

22. Проєкт Закону України «Про сільський та сільський зелений туризм». URL: http://w1.c1.rada.gov.ua/pls/zweb2/webproc4_2?pf3516=4299\&skl=5.

23. Савченко В. Ф., Стойка В. О. Проблеми т перспективи розвиту сільського туризму в Україні. Науковий вісник ЧДІЕУ. 2010. № 4(8). С. 5-13.

24. Сердюкова О. М. Сутність сільського зеленого туризму. Економіка та держава. 2014. № 3. С. 87-90.

25. Сільський зелений туризм. Рекомендаційний бібліографічний список «Сільський зелений туризм». URL: https://library.pl.ua/nashi_vidannja/inshi_vidannja/silskij_zelenij_turizm.

26. Смолій В. А., Федорченко В. К., Цибух В. І. Зелений туризм. Енцุиклопедичний словникдовідник з туризму. Київ: Слово, 2006. 372 с. URL: https://leksika.com.ua/12041219/turizm/ turizm zeleniy.

27. Смолій В. А., Федорченко В. К., Цибух В. І. Туризм екологічний (еконтуризм). Енщиклопедичний словник-довідник з туризму. Київ: Слово, 2006. 372 с. URL: https://leksika.com.ua/15590911/turizm/turizm_ekologichniy_ekoturizm.

28. Транченко Л. В., Тымчук С. В., Нещадим Л. Н. Социальное значение зеленого туризма в контексте развития сельских территорий Украины. Современные технологии управления. 2015. №1 (49). C . 43-47. URL: https://sovman.ru/article/4908.

29. Туєва О. М. Правові умови забезпечення діяльності у сфері зеленого туризму. Порівняльно-аналітичне право: електрон. наук. фах. вид. юрид. ф-ту ДВНЗ «Ужгород. нац. ун-т». 2017. № 3. C. 103-106. 
ГАЛУЗЕВИЙ АСПЕКТ РОЗВИТКУ НАЦІОНАЛЬНОГО ГОСПОДАРСТВА

30. Язіна В. А., Ткач В. О., Кожушко С. П. Сільський зелений туризм як основний інструмент створення успішного українського туристичного села. Причорноморські економічні студіï. 2018. Вип. 29. С. 37-41.

31. Gryshova I., Shabatura T., Nikoliuk O. State regulation of ecotourism in the context of European experience. The Scientific Papers of the Legislation Institute of the Verkhovna Rada of Ukraine. 2020. № 1. C. 126-136. URL: https://instzak.com/index.php/journal/article/view/1783.

\section{References}

1. Byrkovych, V. I. (2008). Silskyi zelenyi turyzm - priorytet rozvytku turystychnoi haluzi Ukrainy [Rural green tourism - a priority of the tourist industry development of Ukraine]. Stratehichni priorytety - Strategic priorities, 1 (6), 138-143 [in Ukrainian].

2. Vasyliev, V. (2008). Holovna meta silskoho turyzmu - tse novyi turystychnyi product [The main purpose of rural tourism is a new tourist product]. Turyzm silskyi zelenyi - Tourism is rural green, 4, 10-13 [in Ukrainian].

3. Vasyliev, V. P. (n.d.). Silskyi zelenyi turyzm v Ukraini [Rural green tourism in Ukraine]. Retrieved from http://tourlib.net/statti_ukr/vasyljev.htm.

4. Vlasenko, I. V., Ivashchenko, H. V. (2017). Funktsionuvannia silskoho zelenoho turyzmu v umovakh rynkovoi ekonomiky Ukrainy [Functioning of rural green tourism in the conditions of market economy of Ukraine]. Ekonomichna stratehiia i perspektyvy rozvytku sfery torhivli ta posluhEconomic strategy and prospects for the development of trade and services, 1 (25), 218-233 [in Ukrainian].

5. Habchak, N. (2008). Silskyi turyzm Zakarpattia [Rural tourism in Transcarpathia]. Zbirnyk naukovykh statei vykladachiv kafedry suspilnykh dystsyplin Zakarpatskoho derzhavnoho un-tu Collection of scientific articles of teachers of the Department of Public Disciplines of Transcarpathian State University, 2, 12-19 [in Ukrainian].

6. Honcharov, Yu. V. (2014). Silskyi zelenyi turyzm yak perspektyvnyi napriam rozvytku zahalnoho pidnesennia ekonomichnoho rivnia rehionu [Rural green tourism as a promising direction for the development of the general uplift of the economic level of the region]. Intelekt XXI Intelligence XXI, 3, 41-45 [in Ukrainian].

7. Horishevskyi, P. V., Vasyliev, V. P., Zinko, Yu. V. (2003). Silskyi zelenyi turyzm: orhanizatsiia hostynnosti na seli [Rural green tourism: organization of hospitality in the countryside]. IvanoFrankivsk: Misto-N [in Ukrainian].

8. Horovyi, V. P., Tymchuk, S. V. (2014). Menedzhment fermerskyi hospodarstv [Farm Management]. Kyiv: TsUL. Retrieved from https://pidruchniki.com/1278021261738/menedzhment/sotsialnoekonomichne_znachennya_fermerskogo_turizmu_konteksti_rozvitku_silskih_teritoriy_ukrayiniiu.

9. Darchük, V. H. (2014). Formuvannia stratehichnykh osnov rozvytku silskoho (zelenoho) turyzmu v Ukraini [Formation of strategic bases for the development of rural (green) tourism in Ukraine] (Candidate's thesis). Donets. nats. un-t ekonomiky i torhivli im. Mykhaila TuhanBaranovskoho, Donetsk [in Ukrainian].

10. Didyk, N. V., Varshava, O. V. (2017). Rozvytok zelenoho turyzmu - priorytetne zavdannia dlia Ukrainy [Green tourism development is a priority for Ukraine]. Ekonomika ta suspilstvo Economy and society, 9, 763-767 [in Ukrainian].

11. Dobrianska, N. A., Stoianova-Koval, S. S., Nikoliuk, O. V. (2018). Realii sohodennia ta perspektyvy rozvytku turystychnoho biznesu Odeskoi oblasti [Realities of the present and prospects of tourism business development in Odessa region]. Ekonomika kharchovoi promyslovosti - Economics of the food industry, 10(1), 9-15 [in Ukrainian].

12. Dubyna, M. V., Pilevych, D. S. (2014). Problemy aktyvizatsii formuvannia ta zaluchennia investytsii u rozvytok natsionalnoi ekonomiky [Problems of activation of formation and attraction of investments in the national economy development]. Naukovyi Visnyk: finansy, banky, investytsii Scientific Bulletin: finance, banks, investments, 1(26), 94-101 [in Ukrainian].

13. Informatsiino-analitychnyi portal APK Ukrainy [Information-analytical portal of AIC of Ukraine]. Retrieved from https://agro.me.gov.ua/ua/napryamki/rozvitok-silskih-teritorij/silskij-turizm.

14. Kyfiak, V. F. (2003). Orhanizatsiia turystychnoi diialnosti v Ukraini [Organization of tourist activity in Ukraine]. Chernivtsi: Knyhy-XXI. Retrieved from http://tourlib.net/books_ukr/kyfjak_3.htm.

15. Mazur, S. A. (2018). Silskyi turyzm yak perspektyvnyi napriam rozvytku vnutrishnoho turyzmu [Rural tourism as a perspective direction of the domestic tourism development]. Efektyvna ekonomika An efficient economy, 2. Retrieved from http://www.economy.nayka.com.ua/?op=1\&z=6122. 
ГАЛУЗЕВИЙ АСПЕКТ РОЗВИТКУ НАЦІОНАЛЬНОГО ГОСПОДАРСТВА

16. Matviienko, A. T. (2014). Zelenyi turyzm yak napriamok vyrishennia problemy zainiatosti silskoho naselennia v Ukraini [Green tourism as a direction of solving the problem of employment of the rural population in Ukraine]. Ekonomichnyi visnyk universytetu - University Economic Bulletin, 22(1), 95-99. Retrieved from http://nbuv.gov.ua/UJRN/ecvu_2014_22\%281\%29_18.

17. Pysarevskoho, I. M. (2008). Orhanizatsiia turyzmu [Tourism organization]. Kharkiv: KhNAMH [in Ukrainian].

18. Papp, V. V. (2015). Silskyi zelenyi turyzm yak priorytetnyi napriam rozvytku silskykh terytorii Ukrainy [Rural green tourism as a priority direction for the rural development in Ukraine]. Ahrosvit-Agro-world, 18, 17-22 [in Ukrainian].

19. Pylypenko, H. M., Prushkivska, E. V., Kusakova, Yu. O. (2016). Komparatyvnyi analiz rozvytku zelenoho turyzmu $\mathrm{v}$ Ukraini ta sviti [Comparative analysis of the green tourism development in Ukraine and the world]. Ekonomichnyi visnyk - Economic Bulletin, 3, 145-153 [in Ukrainian].

20. Pro osobyste selianske hospodarstvo [On Individual Farm]. № 742-IV (on May 15, 2003). Retrieved from https://zakon.rada.gov.ua/laws/show/742-15/print.

21. Pro turyzm [On Tourism]. № 324/95-VR (on September 15, 1995). Retrieved from https://zakon.rada.gov.ua/laws/show/324/95-\%D0\%B2\%D1\%80/print. 1H.

22. Proiekt Zakonu Ukrainy "Pro silskyi ta silskyi zelenyi turyzm» [Draft Law of Ukraine "On Rural and Rural Green Tourism"]. Retrieved from http://w1.c1.rada.gov.ua/pls/ zweb2/webproc4_2?pf3516=4299\&skl=5.

23. Savchenko, V. F., Stoika, V. O. (2010). Problemy t perspektyvy rozvytu silskoho turyzmu v Ukraini [Problems and perspectives of rural tourism development in Ukraine]. Naukovyi visnyk ChDIEU - Scientific Bulletin of the ChSEU, 4(8), 5-13[in Ukrainian].

24. Serdiukova, O. M. (2014). Sutnist silskoho zelenoho turyzmu [The essence of rural green tourism]. Ekonomika ta derzhava - Economy and the state, 3, 87-90 [in Ukrainian].

25. Silskyi zelenyi turyzm. Rekomendatsiinyi bibliohrafichnyi spysok «Silskyi zelenyi turyzm» [Rural green tourism. Rural Green Tourism Recommended Bibliographic List]. Retrieved from https://library.pl.ua/nashi_vidannja/inshi_vidannja/silskij_zelenij turizm.

26. Smolii, V. A., Fedorchenko V. K., Tsybukh V. I. (2006). Zelenyi turyzm. Entsyklopedychnyi slovnyk-dovidnyk z turyzmu [Green tourism. Encyclopedic Dictionary-Directory on Tourism]. Kyiv: Slovo. Retrieved from https://leksika.com.ua/12041219/turizm/turizm_zeleniy.

27. Smolii V. A., Fedorchenko V. K., Tsybukh V. I. (2006). Turyzm ekolohichnyi (ekonturyzm). Entsyklopedychnyi slovnyk-dovidnyk z turyzmu [Environmental tourism (ecotourism). Encyclopedic Dictionary-Directory on Tourism]. Kyiv: Slovo. Retrieved from https://leksika.com.ua/15590911/ turizm/turizm_ekologichniy_ekoturizm.

28. Tranchenko, L. V., Tymchuk, S. V., Neshchadym, L. N. (2015). Sotsialnoe znachenie zelenogo turizma $\mathrm{v}$ kontekste razvitiia selskykh territorii Ukrainy [Social significance of green tourism in the context of the rural development of Ukraine]. Sovremennye tekhnologii upravleniia - Modern mangement technologies, 1 (49), 43-47. Retrieved from https://sovman.ru/article/4908.

29. Tuieva, O. M. (2017). Pravovi umovy zabezpechennia diialnosti u sferi zelenoho turyzmu [Legal conditions for providing activities in the field of green tourism]. Porivnialno-analitychne pravo - Comparative analytical law, 3, 103-106 [in Ukrainian].

30. Iazina, V. A., Tkach, V. O., Kozhushko, S. P. (2018). Silskyi zelenyi turyzm yak osnovnyi instrument stvorennia uspishnoho ukrainskoho turystychnoho sela [Rural green tourism as the main tool for creating a successful Ukrainian tourist village]. Prychornomorski ekonomichni studii - Black Sea Economic Studies, 29, 37-41 [in Ukrainian].

31. Gryshova, I., Shabatura, T., Nikoliuk, O. (2020). State regulation of ecotourism in the context of European experience. The Scientific Papers of the Legislation Institute of the Verkhovna Rada of Ukraine, 1, 126-136. Retrieved from https://instzak.com/index.php/journal/article/view/1783.

|Гакал Тетяна Олександрівна - аспірантка, Херсонський державний аграрний університет (вул. Стрітенська, 23, м. Херсон, 73006, Україна).

Гакал Татьяна Александровна - аспирантка, Херсонский государственный аграрный университет (ул. Сретенская, 23, г. Херсон, 73006, Украина).

Hakal Tetiana - PhD Student, Kherson State Agrarian University (23 Stritenska Str., 73006 Kherson, Ukraine).

E-mail: 2606147@ukr.net

Гакал Т. Науково-концептуальні положення обгрунтування сутності категорії «сільський зелений туризм». Проблеми $і$ перспективи економіки та управління. 2019. № 4 (20). С. 187-197. 